Рибидайло А. А., к.т.н., с.н.с.;

Турейчук А. М., к.т.н.;

Левшенко О. С.;

Прокопенко О. С.

Центр воєнно-стратегічних досліджень Національного університету оборони України імені Івана Черняховського, Київ

\title{
Порядок оцінювання службової діяльності військовослужбовців в особливий період
}

Резюме. Запропоновано порядок оцінювання службової діяльності військовослужбовців у бойових умовах та надані практичні рекомендації щодо складання атестацій на підлеглих військовослужбовців після перебування в зоні антитерористичної операції (АТО).

Ключові слова: модель функціонального стану, підготовка і оцінювання військовослужбовців, психологічний стан, щорічне оцінювання, атестаційна картка.

Постановка проблеми. У рамках шести минулих хвиль мобілізації в 2014-2015 роках на військову службу були залучені 210 тисяч чоловік. Три хвилі були проведені в 2014 році, і ще три в 2015 році.

Сьома хвиля, була запланована на травень-червень і жовтень-листопад 2016 року. Проте на початок 2016 року більше 23 тисяч українців підписали контракт на службу у Збройних Силах (3С) України та інших силових підрозділах, що дало можливість не оголошувати сьому хвилю мобілізації. Держава ще не оголосила повну відмову від мобілізації або призову, але з кінця минулого року підрозділи комплектують контрактниками. При цьому Президент України підкреслив, що у рамках чергових призовів планується залучати військовослужбовців із досвідом, тих, хто вже проходив строкову службу, брав участь в антитерористичній операції на Сході країни, брав участь у бойових діях і має військовий досвід. Обсяги набору залежатимуть від тих бойових частин, яким потрібно доукомплектування, і політичної обстановки в регіоні [1].

За підсумками наради керівництва українських силових структур, начальник Генерального штабу 3С України підкреслив: "Пріоритетом кадрової політики Збройних сил України цього року повинне стати продовження процесу професіоналізації армії за рахунок якісного комплектування штатних офіцерських посад". Він зазначив, що у 3С України "вистачає хороших виконавців, але цього мало, ми відчуваємо нестачу в лідерах. Кадрова робота має бути спрямована на пошук лідерів i формування лідерських якостей”. Необхідність у таких змінах диктується тим, що українська армія 3 минулого року комплектується в основному контрактниками, людьми, більшість 3 яких мають освіту, життєвий і професійний досвід. За два роки війни в Донбасі контракти були укладені 385 тис. військовослужбовців. Чисельність військовослужбовців строкової служби у ЗС України складає зараз тільки $10 \%$ [2].

Таким чином, важливими завданнями кадрового менеджменту в умовах особливого періоду $є$ :

зупинення відтоку кваліфікованих спеціалістів із ЗС України, які мають досвід виконання завдань у зоні проведення антитерористичної операції;

накопичення резерву кандидатів для просування по службі, які спроможні якісно виконувати обов'язки за вищими посадами в умовах ведення бойових дій;

комплектування органів військового управління 3С України якісним персоналом, 3 наявним бойовим досвідом, здатним виконувати специфічні завдання військової служби в умовах особливого періоду.

Для вирішення зазначених завдань доцільно спиратися на результати оцінювання особового складу в умовах особливого періоду. Враховуючи, що в особливий період оцінювання службової діяльності військовослужбовців та їх атестування нормативними актами не передбачено, нагальною потребою є розроблення “Інструкції оцінювання службової діяльності військовослужбовців в особливий період (бойових умовах)”, де має бути розтлумачено порядок проведення оцінювання службової 
діяльності військовослужбовця в особливий період.

Аналіз останніх досліджень і публікацій. У відкритих джерелах достатня кількість робіт, наприклад [3-5], присвячена питанням психологічної підготовки військовослужбовців для успішного ведення бойових дій.

У [3] детально розглядаються питання психологічного стану військовослужбовців і чинники, що його визначають в умовах бойової діяльності, способи саморегуляції і підвищення психологічного стану. У роботі [4] розроблені підходи до організації i проведення психологічної підготовки військовослужбовців. Погляди військових психологів на зміст загальної, цільової і спеціальної психологічної підготовки, а також психологічна модель сучасного бою розглянуті в [5].

Питання, що стосуються порядку оцінювання військовослужбовців у бойових умовах, висвітлені фрагментарно.
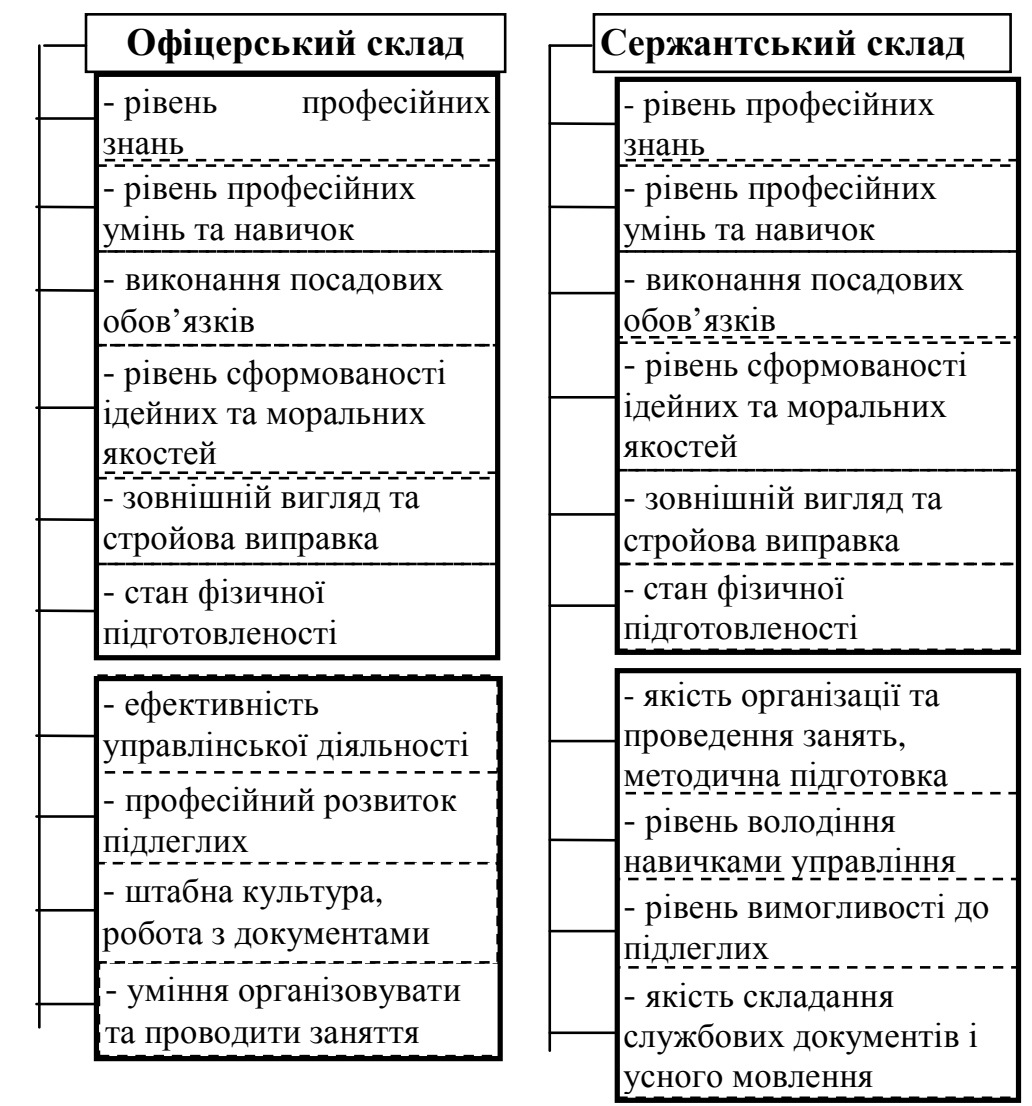

Метою статті є обгрунтування підходу щодо розроблення i використання порядку оцінювання службової діяльності військовослужбовців у бойових умовах.

Виклад основного матеріалу. Оцінювання результатів службової діяльності військовослужбовця здійснюється за допомогою оцінки за критеріями та тексту оцінної характеристики.

В умовах мирного життя за результатами оцінювання і атестування військовослужбовців (щорічне оцінювання, періодична атестація та незалежне оцінювання) складається оцінна картка, у другому розділі якої приводиться оцінка за критеріями службової діяльності, а в третьому - текст оцінної характеристики та пропозиції безпосереднього начальника. Таким чином, можна стверджувати, що модель функціонального стану військовослужбовців (за категоріями) для умов мирного часу вже існує. Структурно іï можна подати у вигляді, наведеному на рис. 1.

\section{ОЦННА ХАРАКТЕРИСТИКА ТА ПРОПОЗИЦЇ БЕЗПОСЕРЕДНЬОГО НАЧАЛЬНИКА}

Рис. 1. Модель функціонального стану військовослужбовців

Аналіз моделі функціонального стану військовослужбовців дає змогу дійти наступних висновків:

- оцінка

різних

категорій військовослужбовців за критеріями службової діяльності має спільні складові - базова підготовка може проводитись за типовими методиками; - подальша

підготовка військовослужбовців за категоріями має використовувати спеціальні методики. 
У роботі [6] запропоновано підхід до моделювання критичних ситуацій, основним змістом якого $є$ структуризація критичних ситуацій за визначеними ознаками та врахування особливостей зони конфлікту (зони АТО). У залежності від джерела виникнення, критичні ситуації поділяються на ситуації природного, техногенного, воєнного та соціально-політичного характеру. Дії військовослужбовців щодо подолання означених ситуацій мають бути відпрацьовані на підготовчих зборах мобілізаційного резерву.

Враховуючі зміст моделі імовірних критичних ситуацій, основну увагу при формуванні адекватного функціонального стану військовослужбовців слід приділяти підвищенню рівня професійних знань, професійних умінь й навичок та сформованості ідейних і моральних якостей.

Спільне використання моделі імовірних критичних ситуацій та функціонального стану військовослужбовців для оцінки службової діяльності військовослужбовців (рис. 1) дає змогу розв'язати низку часткових задач, які виникають при формуванні порядку оцінювання службової діяльності військовослужбовців в особливий період:

розробити додаткові підкритерії оцінювання службової діяльності за складовими: рівень професійних знань, рівень професійних умінь та навичок та рівень сформованості ідейних та моральних якостей; обгрунтувати додаткові спільні предмети навчання;

обгрунтувати додаткові роздільні предмети навчання.

У роботі [7] було розроблено алгоритм роботи кадрових органів для оцінювання службової діяльності військовослужбовців у бойових умовах, який складається 3 трьох блоків:

навчання та первинне атестування;

заходи, що проводяться протягом перебування військовослужбовців у бойових умовах;

заключні заходи.

Спираючись зазначені результати досліджень $[6,7]$, можна запропонувати порядок оцінювання службової діяльності військовослужбовця в особливих умовах, а саме:

перший етап - аналіз результатів оцінювання виконання службових обов'язків підлеглим особовим складом за результатами навчання (підготовки) в учбовому центрі (полігоні); другий етап - накопичення відомостей про виконання службових обов'язків підлеглими безпосередньо в бойових умовах;

третій етап - складання атестацій на підлеглих військовослужбовців після перебування в зоні АТО.

Особливість першого етапу полягає у тому, що попередня оцінка дій військовослужбовця проводиться в учбових центрах, полігонах, учбових закладах. Обмеженість термінів і насиченість програми навчання вимагає від командирів (інструкторів) досконалого вивчення особливостей підлеглих військовослужбовців. На полігонах проводяться контрольні заняття 3 основних предметів бойової підготовки (вогнева, тактична, тактико-спеціальна, спеціальна, льотна і морська підготовка, водіння бойових машин та автомобілів, медична тощо) та оцінюється індивідуальна підготовка військовослужбовців. У ході занять проводяться контрольні і залікові стрільби, на яких оцінюють виучку особового складу та методичну майстерність у проведенні заходів бойової підготовки їх командирів.

На другому emani накопичуються дані про дії підлеглих військовослужбовців в особливих умовах, для чого використовується така форма як “спостереження", яке здійснюється безпосереднім начальником.

Спостереження може бути систематичним, постійним і несистематичним (епізодичним).

Але в обох випадках воно планується i здійснюється у певній послідовності, а саме:

чітко визначається мета спостереження; вказується його об'єкт і предмет (ситуації, що дають змогу отримати потрібні відомості);

формулюються основні завдання, конкретизуються вид або спосіб спостереження;

готується певне місце для спостереження і визначається його час; розробляється процедура фіксації результатів спостереження; здійснюється збір інформації (власне спостереження);

здійснюється обробка і аналіз отриманої інформації.

Оцінювання службової діяльності в особливий період доцільно проводити за спрощеними процедурами і правилами, а саме: оцінювати діяльність військовослужбовців за трьома або чотирма критеріями:

три критерії оцінок: “так”; “ні”; “не оцінено"; 
чотири критерії оцінок: “добре”; командиром дій підлеглого.

"задовільно”; “не задовільно; "не оцінено”.

Критерій "не оцінено” застосовується у випадках неможливості достовірної оцінки

Оцінку діяльності військовослужбовців можна проводити за показниками, які зведено у табл. 1.

Таблиця 1

\begin{tabular}{|c|c|c|}
\hline № & Показник & Критерії оцінки \\
\hline 1 & $\begin{array}{l}\text { Ступінь усвідомлення поставленої задачі } \\
\text { адекватність її сприймання }\end{array}$ & “добре”; “задовільно”; “незадовільно” \\
\hline 2 & $\begin{array}{l}\text { Наскільки сформовані навички дій у прогнозованих } \\
\text { умовах }\end{array}$ & “добре”; “задовільно”; “незадовільно” \\
\hline 3 & Наскільки розвинене почуття колективізму & “добре”; “задовільно”; “незадовільно” \\
\hline 4 & Ступінь психологічної сумісності & “добре”; “задовільно”; “незадовільно” \\
\hline 5 & $\begin{array}{l}\text { Відсоток позитивних станів (підйому, бойового } \\
\text { збудження, рішучості) }\end{array}$ & $\begin{array}{l}\text { Оцінюється при виконанні } \text { особистих } \\
\text { завдань }\end{array}$ \\
\hline 6 & $\begin{array}{l}\text { Відсоток негативних станів (занепокоєння, страх, } \\
\text { тривога, невпевненість) }\end{array}$ & 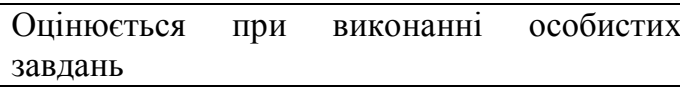 \\
\hline 7 & Характер реакцій на інформацію про майбутні дії & “адекватний”; “неадекватний” \\
\hline 8 & $\begin{array}{l}\text { Спроможність протистояння iнформаційно- } \\
\text { психологічному впливу }\end{array}$ & “добре”; “задовільно”; “незадовільно” \\
\hline 9 & $\begin{array}{l}\text { Уміння надавати первинну медичну допомогу при } \\
\text { отруєннях, пораненнях, обпаленнях тощо }\end{array}$ & $\begin{array}{l}\text { “добре”; “задовільно”; “незадовільно”; } \\
\text { “не оцінено”/“так”; “ні”; “не оцінено” }\end{array}$ \\
\hline 10 & $\begin{array}{l}\text { Уміння виявляти отруйні речовини на зруйнованих } \\
\text { промислових спорудах }\end{array}$ & $\begin{array}{l}\text { “добре”; “задовільно”; “незадовільно”; } \\
\text { “не оцінено”/“так”; “ні”; “не оцінено” }\end{array}$ \\
\hline 11 & $\begin{array}{lccc}\text { Ступінь оволодіння } & \text { способами } & \text { захисту } & \text { від } \\
\text { небезпечних речовин у повітрі, воді, грунті } & \end{array}$ & $\begin{array}{l}\text { “добре”; “задовільно”; “незадовільно”; } \\
\text { “не оцінено”/“так”; “ні”; “не оцінено” }\end{array}$ \\
\hline 12 & $\begin{array}{l}\text { Ступінь оволодіння способами протипожежного } \\
\text { захисту }\end{array}$ & $\begin{array}{l}\text { “добре”; “задовільно”; “незадовільно”; } \\
\text { “не оцінено”/“так”; “ні”; “не оцінено” }\end{array}$ \\
\hline 13 & Стан фізичної підготовленості & “добре”; “задовільно”; “незадовільно” \\
\hline
\end{tabular}

Tретій етап оичнювання службової діяльності військовослужбовців в особливий період здійснюється після ротації частин (підрозділів) або звільнення військовослужбовця 3 лав ЗС України. Ця процедура необхідна для обліку даних щодо подальшого проходження військової служби для кадрових військовослужбовців або для надання відповідних даних у військкомати щодо звільнених військовослужбовців.

Результатом оцінювання дій військовослужбовця повинні стати "Оцінна картка" та “Атестаційна характеристика", які відпрацьовує командир за результатами виконання службової діяльності в особовий період.

Підходи при вивченні та оцінці діяльності кожного військовослужбовця в особливий період, перелік пунктів оцінювання відбирається виходячи 3 того, наскільки успішними та результативними були бойові дії за час перебування в зоні АТО.

Порядок оцінювання службової діяльності військовослужбовця в бойових умовах можна подати у вигляді, як зображено на рис. 2. Для того, щоб виконати завдання другого етапу, а саме, накопичення відомостей про виконання службових обов'язків підлеглими, безпосередньо, в бойових умовах, командири всіх рангів мають пройти певну підготовку, де основну увагу слід зосередити на вивченні методичних рекомендацій щодо оцінювання військовослужбовців у бойових умовах та аналіз сутності додаткових показників оцінювання. Складання атестацій на підлеглих військовослужбовців після перебування в зоні ATO (третій етап) теж потребує окремого тлумачення.

Слід також зазначити, що досвід ведення бойових дій показав, що психологічний стан військовослужбовців, їх моральна готовність до ведення бойових дій, $\epsilon$ однією 3 головних складових бойової готовності військ до бойових дій. Враховуючи це, можна стверджувати про необхідність оцінювання морально-психологічних якостей військовослужбовців.

На сьогодні не існує методичного підгрунтя щодо оцінювання психологічної готовності військовослужбовця особисто і колективу в цілому до виконання завдань в екстремальних умовах. На погляд авторів, саме на вирішенні цього питання доцільно зосередити увагу профільних наукових закладів при здійсненні подальших досліджень. 


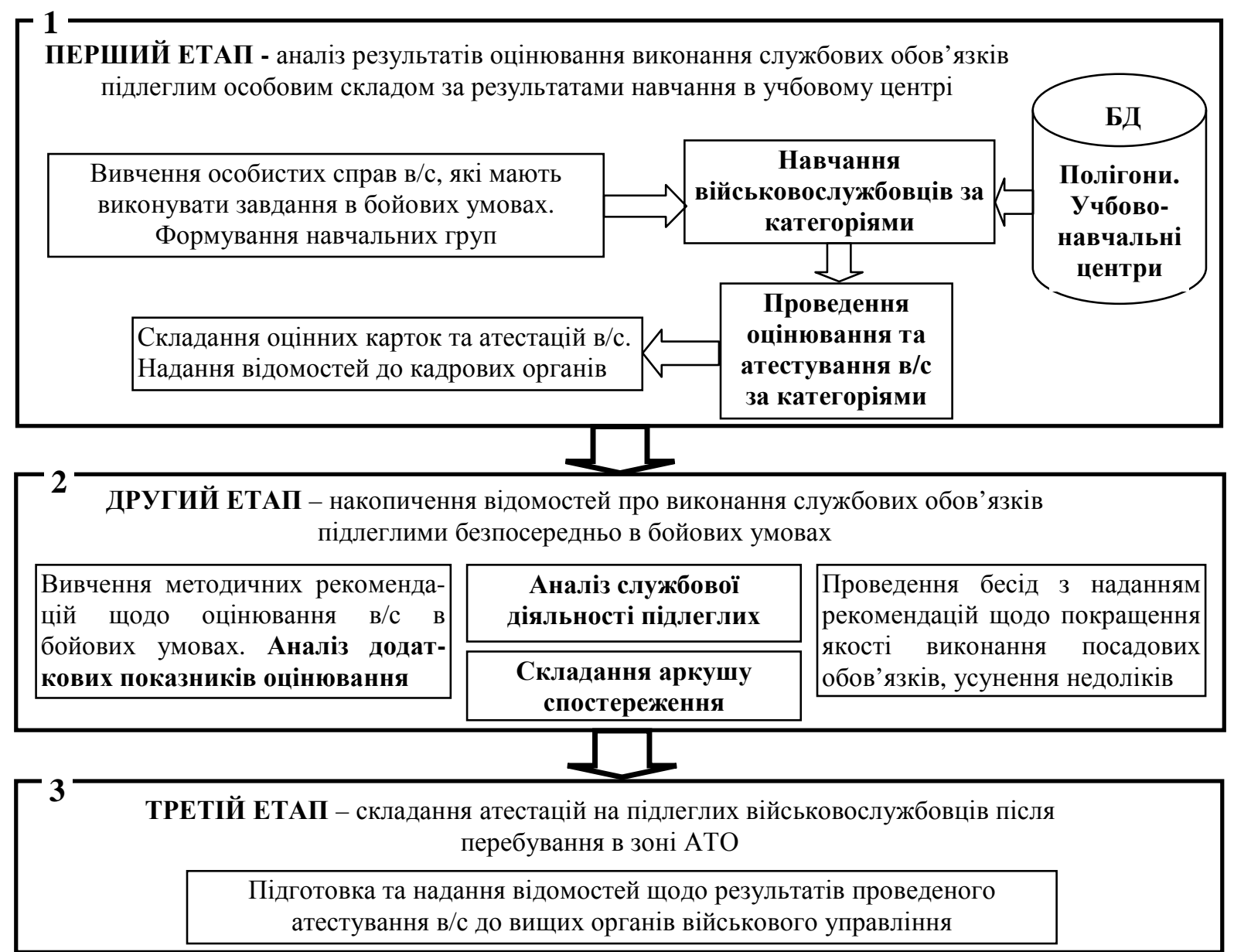

Рис. 2. Порядок оцінювання службової діяльності військовослужбовця в бойових умовах

Висновки. Запропонований порядок оцінювання службової діяльності військовослужбовця в бойових умовах передбачає здійснення певних організаційних заходів із боку органів кадрового менеджменту:

адаптація існуючої системи оцінювання особового складу до умов особливого періоду; організація навчання i атестування особового складу в учбово-навчальних центрах і полігонах;

підготовка командирів i начальників всіх рангів до виконання завдань 3 оцінювання службової діяльності військовослужбовця в бойових умовах.

Практичне значення виконання цих завдань полягає в удосконаленні методики та наданні практичних рекомендацій щодо проведення оцінювання службової діяльності військовослужбовців в особливий період, визначення їх рейтингу та складання резерву кандидатів для просування по службі в особливий період, що надасть можливість ефективніше призначати офіцерів на посади, особливо до органів військового управління.

\section{СПИСОК ВИКОРИСТАНОЇ ЛІТЕРАТУРИ}

1. Особенности проведения мобилизации в 2017 году в Украине. Режим доступу: http://antikor.com.ua/articles/138615-

osobennosti_provedenija_mobilizatsii_v_2017_godu_ v_ukraine.

2. Киев приступил уже к седьмой волне мобилизации Режим доступу: http://www.ng.ru/cis/2017-01-12/1_6900_kiev.html.

3. А. Колосов Психологические состояния военнослужащих. Режим доступа: http://voenn.info/docs/ogp/ogp-k1/2012/2012-052.shtml.

4. Психологическая подготовка военнослужащих к ведению активных боевых действий. Режим доступа: http://refac.ru/tema-4-psixologicheskayapodgotovka-voennosluzhashhix-k-vedeniyu-aktivnyxboevyx-dejstvij/

5. Корчемный П. А. Военная психология: методология, теория, практика, 2010. Режим доступа: http://medicinapediya.ru/psihologiya-pedagogikavoennaya/psihologicheskaya-podgotovkavoennoslujaschih-38879.html

6. Рибидайло А. А. Моделювання імовірних критичних ситуацій для оцінки службової діяльності військовослужбовців (військових підрозділів) в особливих умовах / А. М. Турейчук, О. С. Прокопенко, О. С. Левшенко //, Збірник наукових праць ЦВСД НУОУ, м. Київ, 2016. - № 2(57) - C. 80-86. 
7. Рибидайло А. А. Обгрунтування підходу щодо створення алгоритму роботи кадрових органів для оцінювання службової діяльності військовослужбовців умовах / А. М. Турейчук,

О. С. Прокопенко, О. С. Левшенко //, Збірник наукових праць ЦВСД НУОУ, м. Київ, 2016. - № 3(58) - С. 54-59.

Стаття надійшла до редакції 27.01.2017

Рыбыдайло А. А., к.т.н., с.н.с.;

Турейчук А. Н., к.т.н.;

Прокопенко А. С.;

Левшенко А. С.

Центр военно-стратегических исследований Национального университета обороны Украины имени Ивана Черняховского, Киев

Порядок оценивания служебной деятельности военнослужащих в особый период

Резюме. Предложен порядок оценивания служебной деятельности военнослужащих в боевых условиях и представлены практические рекомендации относительно составления аттестаций на подчиненных военнослужащих после пребывания в зоне антитеррористической операции (АТО).

Ключевые слова: модель функционального состояния, подготовка и оценивание военнослужащих, психологическое состояние, ежегодное оценивание, аттестационная карточка.

A. Rybydajlo, Ph. D;

A. Tureychuk, Ph. D;

A. Prokopenko;

A. Levshenko

Center for Military and Strategic Studies National Defence University of Ukraine named after Ivan Chernyhovsky, Kyiv

Order of evaluation of official activity of servicemen in a special period

Resume. The order of evaluation of official activity of servicemen is offered in battle conditions and practical recommendations are presented in relation to drafting of attestations on inferior servicemen after a stay in the zone of anti-terror operation (ATO).

Keywords: model of the functional state, preparation and evaluation of servicemen, psychological state, annual evaluation, attestation card. 